\title{
Design and Development of Material Management System Based on Digital Pulp Pipeline
}

\author{
H.W. Liu \\ Yunnan Da Hongshan Pipeline Co., Ltd. \\ Kunming, China
}

\author{
J.D. $\mathrm{Wu}$ \\ Engineering Research Center for Mineral Pipeline \\ Transportation YN \\ Kunming, China
}

\author{
Z.L. Yu \\ Faculty of Information Engineering and Automation \\ Kunming University of Science and Technology \\ Kunming, China
}

\begin{abstract}
Material Management is refers to the enterprises to manage the behavior of procurement, use and storage of the necessary materials. It is an important part of the normal production and operation of enterprises, and affects the economic benefits of enterprises directly. At present, most of the material management systems in the enterprise have some problems: different kinds of materials and unreasonable classifications; procuring not timely and inventory backlog; data transformation not timely and data inaccurate, and so on. Aiming at this problem, a material management system based on $\mathrm{B} / \mathrm{S}$ mode was designed. It combines procurement, inventory, audition and other processes, realizing workflow clarity, delivery of information timely, systematization and standardization of material management. The practical application shows that: the system has good practicability.
\end{abstract}

Keywords-material management system; workflow; procurement; audit

\section{INTRODUCTION}

Da Hong Shan Pipeline company has already built a website platform, integrated management and control systems, data acquisition and monitoring of SCADA systems, But for the lack of effective connection and integration between the various platforms, resulting in the management unable to view information timely [1]. A material management system based on $\mathrm{B} / \mathrm{S}$ mode has been designed to solve these problems.

In recent years, with the development of database technology and the database management system, many enterprises have realized the importance of database management system [2]. At present, many enterprises are gradually improving their material management system, although some achievements have been made, there are still many aspects need to be improved [3].
Advanced computer technology, network technology, database technology and management concept can solve problems that the enterprises are facing [4]. The system is designed by the modular design method, and there are connections and differences between various modules, the corresponding module can be added as the development and needs of the enterprises, so it has the good adaptability. Meanwhile, the rapid development of information technology makes business processes clear at a glance, easy for users to understand and operate [5]. In order to ensure the safety of corporate information, different permissions were configured according to different departments, leaders and staff at all levels, it is better to regulate their responsibilities as well as the business related to privacy. The operation of the system shows that: the system can strengthen the links between the various departments, ensure the normal and orderly conduct of materials management activities and improve the efficiency of business operations.

\section{SYSTEM DESIGN SCHEME}

Through the analys is of the life cycle of materials, this paper analyzes each big enterprise's production and operation management standards, and combined with the characteris tics of the enterprise, after repeated research, we divided material management process into six stages: material purchase, material inbound, material change, material allocation, material scrap, and material outbound.

\section{A. Material Purchase}

Each department needs to purchase the goods and submit the procurement plan to the relevant departments of the company, the relevant departments will come to purchase after summarizing the materials from all departments. This process is the beginning of materials coming into company, and its smooth completion is the base of the following process. Material purchase is the starting point of material life cycle. 


\section{B. Material Inbound}

After the completion of the procurement of materials, supplies will be transported to the management department, and management department will make registration materials and notes after receiving the materials.

\section{Material Change}

Material change includes several aspects: changes of material price and quantity in material purchase and material allocation, the normal equipment changes to scrapped equipment or new equipment after maintenance. This process is relatively complex, materials will be forbidden into the next corresponding processes if the materials attribute have changed, and need to return to the former process to re-submit an application after modifying something.

\section{Material Allocation}

Each department can get the materials according to their procurement plan after materials come into the storage, but perhaps department A may not need some certain materials which it has purchased before temporarily, and department Bjust needs the materials which it hasn't purchased before, then the materials can be allocate to department $B$ at this time. This kind of phenomenon is very common in the actual production conditions, in order to improve the work efficiency, material allocation process is very necessary.

\section{E. Material Scrap}

Material scrap generally can be divided into three aspects: First, the purchased materials failed to use or couldn't used; second, materials failed to maintain or maintenance costs are too high; scraped materials are also part of company's property, it can also bring great economic benefits for the company by rational use.

\section{F. Material Outbound}

Material will have outbound proof and note when department takes the purchased materials. We should understand the department of used materials is the department of purchased materials eventually. Material outbound is the end of the life cycle.

The following is function structure chart of material management process:

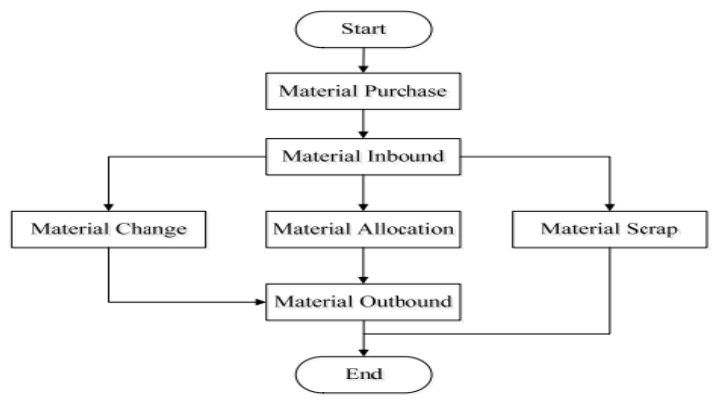

FIGUREI. THE FUNCTION STRUCTURE CHART OF MATERIAL MANAGEMENT PROCESS

\section{ANALYSIS OF THE MAIN WORKFLOW OF MATERIALS MANAGEMENT}

\section{A. Material Purchase}

Material from purchase to inbound can divide into several steps actually: the unit leadership for approval, the branch leadership for approval, material procurement department for purchasing, acceptance of storage. Unit leaders for approval including leaders in charge audit and competent leadership review.

The department submits the material purchase plan after making the plan, leaders in charge will audit firstly, if the plan is reasonable, it will be submitted to the competent leadership, otherwise, it will be rejected with feedback suggestions. Competent leadership will submit the plan to the branch leaders if the plan is reasonable, otherwise, the plan will be rejected with feedback suggestions. The branch leaders will submit the plan to material procurement department if the plan is reasonable, otherwise, the plan will be rejected with feedback suggestions. Purchasing department will accept the material and material inbound process is complete.

The following is flowchart of material purchase and material inbound:

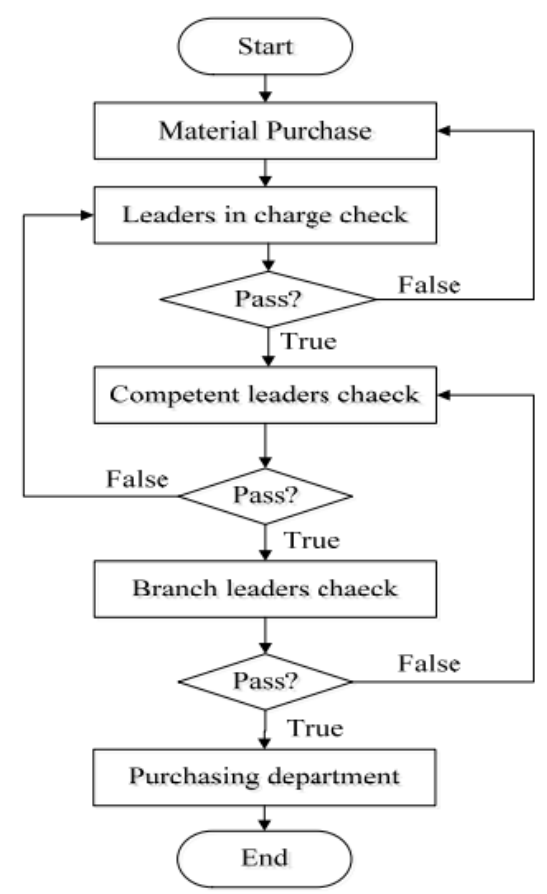

\section{FIGUREII. THE FLOWCHART OF MATERIAL PURCHASE AND MATERIAL INBOUND.}

\section{B. Material Change}

Material change include price change and quantity change, material management department submits the material change to leaders in charge, if the leaders in charge think it is reasonable, then material management department will modify material inventory record the changes, otherwise, then material 
management department will reject the plan and explain the reason.

\section{Material Allocation}

Material allocation is a material transfer process between the used department and the owned department of the material, the owned department of the material will outbound the materials after it checked the materials applied by the used department of the material, the materials will be inbounded after the used department of the material received them.

\section{Material Scrap}

Material scrap means material can't continue to be used, if the material has been used over its safety use year, then it can apply for scraping, after each leader checked and given some advice, the material scrap will be reported to the energy conservation center. Finally, material management department will record material scrap and Charge-offs for materials inventory.

\section{E. Material Outbound}

Material application department submits materials requisition to material management department, and then material management department will check the inventory, if the inventory is sufficient, the competent leadership will arrange materials outbound after checking the outbound plan, and material management department will hander the Charge-offs for materials outbound, then applied department can get the recipients.

\section{CONCLUSIONS}

This paper discusses the design and development of material management systembased on digital pulp pipeline, in addition, it has good reference to solve the problems existing in the enterprise material management. The practice shows: This system can achieve the enterprise materials management, not only ensures the timely supply of material needs and improves employee productivity, but also provides more convenient to know the need of production and the information of material inventory. With the continuous development of information technology, there will be a better material management system, and it would be helpful to provide some reference to people of engaged in developing materials management system.

\section{ACKNOWLEDGEMENT}

This work is supported by National Natural Science Foundation of China (No. 51169007), Science \& Research Program of Yunnan province (No.2011CI017 \& 2012CA022\&2013DH034).

\section{REFERENCES}

[1] CHEN Hua, ZHANG Pengwei, CHEN Jingxia. Design and Implementation of material management system for small and medium enterprises in MIS[J]. Journal of Shaanxi University of Science and Technology,2003,21(6):78-81.
[2] WANG Jianwen, ZHANG Junming, HAN Lipeng. Design and Implementation of Materials Management System based on ExtJS[J].College of Electrical and Information Engineering,2010,23(233):5012-5014,5055.

[3] HE Nixia,YANG Shenghua. Design and Implementation of Enterprise Substances Management System based J2EE Technique System[J]. Development and application of computer, 2005, 06: 26-28.

[4] YANG Bo. Modeling and Development of Material Management System for Power Company Based on UML[J]. Central China Power, 2003,16(3):67-70.

[5] ZHANG Li. Application of Information technology in Material Management System [J]. Modern economic information, 2013, (24): $114-114,117$. 